\title{
Weight Loss through Play-Based Physical Activity for Overweight Children Aged 9-12 Years
}

\author{
Nawan Primasoni ${ }^{1,2, *}$, Sugiyanto ${ }^{1}$, Furqon Hidayatullah ${ }^{1}$, Muchsin Doewes ${ }^{1}$ \\ ${ }^{1}$ Department of Sports Science, Faculty of Sports, Sebelas Maret University, Indonesia \\ ${ }^{2}$ Department of Sports Science, Faculty of Sports Science, Yogyakarta State University, Indonesia
}

Received May 5, 2021; Revised August 11, 2021; Accepted September 8, 2021

\section{Cite This Paper in the following Citation Styles}

(a): [1] Nawan Primasoni, Sugiyanto, Furqon Hidayatullah, Muchsin Doewes, "Weight Loss through Play-Based Physical Activity for Overweight Children Aged 9-12 Years," International Journal of Human Movement and Sports Sciences, Vol. 9, No. 5, pp. 1040 - 1050, 2021. DOI: 10.13189/saj.2021.090526.

(b): Nawan Primasoni, Sugiyanto, Furqon Hidayatullah, Muchsin Doewes (2021). Weight Loss through Play-Based Physical Activity for Overweight Children Aged 9-12 Years. International Journal of Human Movement and Sports Sciences, 9(5), 1040 - 1050. DOI: 10.13189/saj.2021.090526.

Copyright $\bigcirc 2021$ by authors, all rights reserved. Authors agree that this article remains permanently open access under the terms of the Creative Commons Attribution License 4.0 International License

\begin{abstract}
Overweight is the result of a complex interaction between several factors, both non-modifiable and modifiable factors. Modifiable factors include food consumption, lifestyle, and physical activity. If childhood overweight problems continue and are left untreated, it will have a significantly worse impact and can threaten their lives in the future. The most effective and safe method to lose weight is by doing physical activity. This study examines the effectiveness of a play-based physical activity model to lose weight for overweight children aged 9-12 years. This study used an experimental method by involving 20 overweight children aged 9-12 years. Bodyweight measurements were carried out in the control group and the experimental group. The collected data were analyzed using a t-test with SPSS 19 software. The results indicated that: (1) there is a significant effect of play-based physical activity on children's weight loss; (2) the play-based physical activity model is effective for reducing children's weight. The play-based physical activity model needs to be developed and implemented in schools as weight loss strategies for overweight children. The results of this study can be used by sports teachers, instructors, parents, and stakeholders to jointly solve the children's overweight problem. Due to the benefits of physical activity for overweight children, other types of physical activity that can be practiced individually without reducing its enjoyment and satisfaction should be further studied and developed.
\end{abstract}

Keywords Overweight, Physical Activity, Playing

\section{Introduction}

In 2019, 38,000,000 children under five years old were overweight or obese [1]. This health problem occurs not only in developed countries but also in developing countries. Globally, $10 \%$ of school-age children are estimated to have excess body fat and an increased risk of experiencing chronic disease [2]. Childhood obesity and weight problems are also experienced by families with middle to lower socioeconomic conditions [3]. The incidence of overweight is increasing worldwide. At this time, it is estimated that there are 300 million people who suffer from overweight in all global [4]. Research in European Saudi Arabia, namely Italy, Germany, the Netherlands, Romania, Bulgaria, Lithuania, and Turkey, shows that out of 5,206 school children aged 6-11 years, $15.6 \%$ are overweight, and $4.9 \%$ are obese [5]. Asia is the continent with the highest number of overweight men in developing countries, namely $60 \%$ of the population of around 10.6 million people [6]. Reference [7] reports that $20.7 \%$ of Indonesia's population over 18 years is overweight.

Annual health care costs in Southeast Asia for complications related to overweight such as diabetes and heart and blood vessel disease have already reached $\$ 10$ billion. Overweight in China's young generation could spend $\$ 724$ billion in medical costs by 2030. Such 
diseases are an additional burden for the country already struggling to manage primary health care needs [8]. Non-infectious diseases (Non-Communicable Diseases), which are currently occurring in many developed and developing countries, are highly likely to have started with an overweight condition. The social-economic and public health burdens are enormous in developing countries, including Indonesia. Reference [9] points out that being overweight is caused by a phenomenon called the New World Syndrome.

Being overweight is caused by several factors, both non-modifiable and modifiable factors. The non-modifiable factors consist of genetics, ethnicity, gender, and age. Meanwhile, modifiable factors are food consumption, lifestyle, and physical activity [10]. Genetic factors account for $33 \%$ of the effect on a person's body weight. Genes are the dominant factor of overweight, but the environment also influences it. The environment, in this case, includes behavior/ lifestyle (food, meal frequency, and daily activities). A genetic pattern certainly cannot be changed, but diet and activity patterns can be changed [11].

The emergence of various degenerative diseases such as coronary heart hypercholesterolemia, hypertriglyceridemia, diabetes mellitus, hypertension, arthritis/gout, and gallstones are also triggered by obesity [12]. Blood fat levels can cause the emergence of degenerative diseases and shorter life expectancy, incredibly high cholesterol in the blood in people with over fatness, which will harm the heart and blood vessels [13].

Several methods that can be used to treat overweight include exercise, diet, psychological therapy, and surgery [14]. Overweight can also be overcome by using weight-loss drugs, liposuction, acupuncture, and body wraps. One effective method to reduce body fat is diet. However, reference [15] argues that a diet without physical activity will cause a decrease in muscle size which has an impact on metabolism. Several weaknesses of a diet program to lose weight include reducing lean body mass (increasing pure muscle mass / fat-free mass), weak body, lowering basal metabolism, and nutritional deficiencies [16]. Therefore we need a form of physical activity that reduces the risk of being overweight. Sport is one answer to this problem. However, the types of s need to be further examined sports that can reduce the overweight problem.

Reference [17] suggested that exercising is an effective and safe alternative to reduce body fat that does not cause adverse health effects. To lose weight, reducing body fat content can also improve the quality of physical function, such as: increasing muscle strength and endurance, joint flexibility and increasing aerobic fitness, and increasing the mobilization and use of fat. It is necessary to exercise correctly and with the right dose [16]. Jogging and walking is a physical activity recommended by the America College of Sports Medicine and the American
Heart Association [18].

If childhood overweight problems continue and are left untreated, it will have a significantly worse impact and can threaten their lives in the future [4]. Therefore, this study makes a breakthrough in modifying physical activity expected to solve the problem by conducting research and developing a play-based physical activity model to lose weight for overweight children aged 9-12 years.

\section{Methods}

\subsection{Subject}

This study was conducted on 20 overweight male students aged 9-12 years at an elementary school in Sleman, DIY, Indonesia, who wrote consent to participate in the study based on the Informed Content. The criteria for selecting participants in this study were students who had a BMI (Body Mass Index) in the overweight category, namely the more significant than the $85^{\text {th }}$ percentile. Students with BMI less than $85^{\text {th }}$ percentile are students with underweight and normal or healthy weight categories, were not included in the study.

This study used an experimental design by dividing into two groups, namely ten students in the experimental group and ten students in the control group (Figure 1). There was no significant difference between the experimental group and the control group in terms of age, height, and weight $(p>0.05)$ (Table 1).

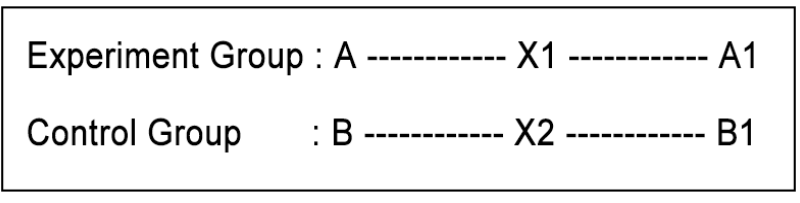

Figure 1. Experiment Design

A, B : initial pre-test

A1, B1 : initial post-test

X1 :Play-based physical activity model for Experiment Group

$\mathrm{X} 2 \quad$ : No specific guidelines for physical activity for Control Group

$$
\text { ------- : Physical Activity Period }
$$

Table 1. General characteristics of the subject $(n=20)$

\begin{tabular}{cccc}
\hline Characteristics & $\begin{array}{c}\text { Experiment } \\
\text { Group }(\mathbf{n = 1 0})\end{array}$ & $\begin{array}{c}\text { Control } \\
\text { Group }(\mathbf{n = 1 0})\end{array}$ & P \\
\hline Age (years) & $11,60 \pm 0,52$ & $11,50 \pm 0,53$ & 0,548 \\
\hline Weight $(\mathrm{kg})$ & $49,33 \pm 4,71$ & $47,12 \pm 8,45$ & 0,222 \\
\hline Height $(\mathrm{cm})$ & $148,0 \pm 6,82$ & $144,0 \pm 7,35$ & 0,914 \\
\hline BMI $(\%)$ & $96,98 \pm 1,64$ & $96,24 \pm 3,33$ & 0,026 \\
\hline
\end{tabular}

Mean \pm standard deviation 


\subsection{Procedure}

In the experimental group, the teacher gave treatment to students to carry out the play-based physical activity for five weeks with a frequency of 5 times per week and a duration of 60 minutes by the play-based physical activity model guidelines (Table 2). The play-based physical activity model is a group game that involves locomotor movements (walking, running, jumping, jumping, crawling), non-locomotor movements (turning, avoiding, twisting, bending, and swinging), and manipulative (throwing, catching, hitting the ball, bouncing the ball, kicking the ball, and dribbling). Then, the game is carried out using a matching system to make it more interesting and fun for children. The training zone used in play-based physical activity is $120-140$ times per minute pulse. Every 10 minutes, the child is guided by the teacher to measure the pulse. Meanwhile, the control group had the same time but was not given special treatment, which means there were no specific rules in physical activity.

\subsection{Assessment}

Measure height using a stadiometer, weight measurement using a digital scale, and BMI using WHO
AnthroPlus 1.0.4 software application. BMI can be known by entering data on the date, month, year of birth, weight, and height. These measurements were carried out before and after the intervention in the experimental and control groups. Table 3 shows the results of the pre-test, post-test, the difference in mean, and the difference in influence between the experimental and control groups.

\subsection{Statistical Analysis}

Statistical measurements of the subject's data were analyzed using SPSS 19 software. The normality test to determine whether the data used was normal or not distributed was carried out through the Shapiro Wilk test. Then the homogeneity test was conducted to determine whether the experimental and control groups' general characteristics were homogeneous before the intervention. Paired samples test was conducted to determine the difference in average body weight and BMI before and after the intervention of each group. An independent samples test was conducted using post-test data to verify the influence difference between the experimental and the control groups. The level of statistical significance was 0.05 .

Table 2. Play-based physical activity model for the experimental group

\begin{tabular}{|c|c|c|c|}
\hline A. & \multicolumn{3}{|c|}{$\begin{array}{l}\text { It consists of } 5 \text { basic concepts of the physical activity model in which the superior and inferior extremities of motion are highlighted } \\
\text { in each form of play with a combination of the tools used }\end{array}$} \\
\hline & Type of Model & Model Material & Strategy \\
\hline 1 . & $\begin{array}{l}\text { Inferior extremity physical } \\
\text { activity model with simple } \\
\text { tools }\end{array}$ & $\begin{array}{l}\text { Activity model in which the legs are } \\
\text { dominant, using assistive devices } \\
\text { such as cones, markers, whistles, } \\
\text { skipping, ladders, ropes, sticks }\end{array}$ & \multirow{5}{*}{$\begin{array}{l}\text { Group play activities, in the form of games, matches, lots } \\
\text { of smiles and laughter, challenges from within and } \\
\text { without. Positive actions, development of flexibility and } \\
\text { creativity, energy surplus }\end{array}$} \\
\hline 2 . & $\begin{array}{l}\text { Superior extremity physical } \\
\text { activity model with simple } \\
\text { tools }\end{array}$ & $\begin{array}{l}\text { An activity model where the hands } \\
\text { and arms are more dominant in } \\
\text { moving, using assistive devices } \\
\text { such as cones, markers, whistles, } \\
\text { skipping, ladders, ropes, sticks }\end{array}$ & \\
\hline 3. & $\begin{array}{l}\text { Superior extremity physical } \\
\text { activity model with a small } \\
\text { ball }\end{array}$ & $\begin{array}{l}\text { Activity model in which the hands } \\
\text { and arms are more dominant in } \\
\text { moving, using assistive devices in } \\
\text { the form of baseballs, tennis balls }\end{array}$ & \\
\hline 4. & $\begin{array}{l}\text { Superior extremity physical } \\
\text { activity model with large ball }\end{array}$ & $\begin{array}{l}\text { Activity model in which the hands } \\
\text { and arms move more dominant, } \\
\text { using assistive devices in the form } \\
\text { of soccer balls, volleyballs, and } \\
\text { basketballs }\end{array}$ & \\
\hline 5. & $\begin{array}{l}\text { Inferior extremity physical } \\
\text { activity model with large }\end{array}$ & $\begin{array}{l}\text { An activity model in which the foot } \\
\text { is dominant, using an assistive } \\
\text { device in the form of a soccer ball }\end{array}$ & \\
\hline B. & \multicolumn{3}{|l|}{ Principles of doing physical activity } \\
\hline \multicolumn{4}{|c|}{$\begin{array}{l}\text { The training zone used in play-based physical activity is } 120-140 \text { times per minute pulse. Every } 10 \text { minutes, the child is guided by the } \\
\text { teacher to measure the pulse }\end{array}$} \\
\hline $\mathrm{C}$. & \multicolumn{3}{|l|}{ Effects of physical activity models } \\
\hline 1. & Effects on body composition & & Lose weight \\
\hline 2. & Effects on psychological & Cultiv & te a sense of pleasure in physical activity \\
\hline
\end{tabular}


Table 3. Comparison of outcome measures before and after the intervention of the experimental and control groups

\begin{tabular}{cccc}
\hline & & Experimental & Control \\
\hline & Weight $(\mathbf{k g})$ & & \\
\hline & Pre & $49,33 \pm 4,71^{\mathrm{a}}$ & $47,12 \pm 8,45$ \\
\hline \multirow{2}{*}{ average difference } & Post & $45,77 \pm 4,75$ & $52,4 \pm 8,38$ \\
\hline difference in influence & Pre and Post & $3,56 \pm 0,91$ & $-5,28 \pm 1,042$ \\
\hline & $\mathrm{p}$ & $.000^{*}$ & $.000^{*}$ \\
\hline & Post and Post (p) & $.043^{+}$ & \\
\hline BMI (\%) & & $96,24 \pm 3,33$ \\
\hline average difference & Pre & $96,98 \pm 1,64^{\mathrm{a}}$ & $99,07 \pm 0,71$ \\
\hline difference in influence & Post & $91,03 \pm 5,72$ & $-2.88 \pm 2,62$ \\
\hline
\end{tabular}

${ }^{a}$ Mean \pm standard deviation, significant difference between before and after intervention (*p 0.05), significant difference in effect after intervention $\left({ }^{+} \mathrm{p}<0.05\right)$

\section{Result}

\subsection{Weight}

There was a significant decrease in BMI after the intervention compared to before the intervention in both groups. The experimental group was $5.95 \%$, while the control group was $2.88 \%(p<0.05)$. In the comparison between groups, there was a significant difference in the effect after the intervention $(\mathrm{p}<0.05)$ (Table 3).

\subsection{BMI}

In the experimental group, there was a significant weight loss after the intervention compared to before the intervention, which was $3.56 \mathrm{~kg}$. Meanwhile, there was a substantial increase in body weight after the intervention in the control group compared to before the intervention, which was $5.28 \mathrm{~kg}$ ( $\mathrm{p}<0.05)$. In the comparison between groups, there was a significant difference in effect $(\mathrm{p}<0.05)$ (Table 3).

\section{Discussion}

Based on play theory, this play-based physical activity model is designed and developed to create a new alternative to the weight loss program for overweight children aged 9 to 12 years. The development process is carried out through several stages, such as a preliminary study to obtain data about the physical activity model carried out by sports teachers for overweight children and the level of physical activity needs for overweight children, as well as the main problem related to overweight children, designing the play-based physical activity model, expert validation tests to prepare the model to be used in the field, small-scale trials, large-scale trials to determine the level of implementation of the model in the field and finally testing the effectiveness of the model applied to overweight children aged 9 to 12 years.

Physical activity is also widely associated with psychological, biological, social, cultural, demographic, and environmental [19]. Kruger revealed that physical activity can be related to a person's quality of life, and encourages research on physical activity recommendations for overweight status [20]. Physical activity is a determining factor for overweight and obesity [21]. Physical activity is essential for children to maintain energy balance, interaction, happiness, and a healthy lifestyle. Steve Stork dan Stephen W. Sanders [22] suggests that physical activity is essential for overall developmental growth in children. It affects a person's body composition. Physical activity can be categorized in terms of frequency, duration, and intensity [23]. Frequency and time are related to how long and how often the physical activity is carried out. Meanwhile, intensity is related to the level of work completed.

This play-based physical activity model was developed by applying several characteristics, needs, and limitations. Overweight children have low heart-lung fitness, so they feel fatigued easily. The physical activity packaged in a game is carried out for 10 to 20 minutes with rest periods. Many physical activity models are designed as an alternative solution to prevent children's boredom. Children who are overweight have adverse physical and psychological effects [24]. Weight loss can also be accomplished with the hypnotherapy method [25]. Science about healthy living, especially food consumption, is an essential factor in controlling children's weight [26].

The play-based physical activity model was designed based on the circumstances and characters of overweight 
children and equipment available in schools. Physical activity is grouped into 1) Superior extremity physical activity with simple tools available in schools, 2) Inferior extremity physical activity using simple tools available in schools, 3) Superior extremity physical activity with a small ball, 4) Physical activity of the superior extremities with a big ball, 5) Physical activity of the significant extremities with a big ball. Furthermore, it is crucial for a weight loss program to determine the concept of play and measure physical activity intensity. All forms of physical activity are carried out with low to moderate intensity, according to research conducted by Agus Salim Samosir, who revealed that moderate-intensity exercise could reduce BMI [27].

Reference [28] emphasized the guidelines of physical activities to lose weight: 1) Aerobic exercise is highly recommended, with low-intensity training, 2). The selected physical activity should create a pleasant and happy atmosphere, 3) Intensity of physical activity uses low to moderate intensity, between 50-70\% VO2max, 3-6 Mets (metabolic equivalent), $60-70 \%$ of maximum heart rate, 4) Physical activity is recommended to be scheduled within one full week, 5) recommended physical activity in the range of 30 minutes to 60 minutes, but preferably 60-120 minutes. Reference [29] suggests that physical activity is more effective than diet to reduce body fat.

A low level of physical activity will affect body weight [30]. Diet and sleep patterns will affect a person's body weight. Obesity is caused by excessive eating and lack of physical activity [31]. Physical activity can be used to predict overweight status [32]. This is consistent with the design of a play-based physical activity model, which will affect weight loss in overweight children. Physical activity shows a significant effect on body weight in children aged 9-12 years after intervention for 6 to 12 weeks [33]. Lack of physical activity is an essential contributing factor to overweight children [34].

Physical activity is a recommended method to lose weight. The intensity, duration, frequency of physical activity are essential components to be considered. In 1998, the National Heart Lung and Blood Institute (NHLBI) recommended moderate intensity 30 to 40 minutes of physical activity for weight loss. Reference [35] shows that in 2001 (ASCM) American College of Sports Medicine recommended 200 to 300 minutes a week of physical activity with moderate intensity. In 2002, (IOM) In 2002, (IOM) Institute of Medicine recommended 60 minutes in one day or 420 in one week of physical activity for weight loss [36]. The effectiveness testing in this study used moderate intensity with a frequency of 5 times a week and 60 minutes.

This play-based physical activity model was created as guidelines for weight loss programs for overweight children to assist sports teachers or fitness instructors in achieving their goal of reducing children's body weight. Before the effectiveness testing of the product, the play-based physical activity model was assessed by several experts to examine the product feasibility. The score analysis obtained from the experts reached a consensus, with $83.59 \%$ of the average percentage from all experts. The play-based physical activity model was declared feasible to be tested in the field. Inputs and suggestions from the experts were used to improve the model. A small-scale and large-scale test was carried out to determine how the product is implemented in the field.

Applying the idea of play during physical activity reduces laziness, anxiety, and boredom. Furthermore, the safety of physical activity is a factor to consider so that children are eager to participate. One of the methods used to keep children engaged in physical activity is to include them in interactions and establish competition opportunities. Various physical activity models are made to eliminate the boredom of monotonous movements. Increased physical activity is a way to avoid feeling stressed [34]. Losing weight will improve health which will then affect happiness [38].

This play-based physical activity model is undergoing successful implementation testing. The aspects of joy and comfort are supporting factors that need to be applied in physical activity. Children are happiest when they can play with teachers and peers at school [39]. If the task is accomplished by playing, children who engage in an enjoyable activity will feel happy [40]. Play activities are very important to encourage children's development and contribute to physical abilities, social happiness, and children's emotional development [41].

Physical activity has a positive relationship with human emotions and quality of life [42]. Children with overweight problems usually have problems related to social relationships and healthy living. The play-based physical activity model will foster self-confidence through activities that are easy, safe, and fun. Physical activity has a positive relationship with happiness levels, besides it also assist in achieving a healthier lifestyle [43]. Children who can enjoy physical activity will live healthier lives, and obesity can be avoided [44]. A high body mass index value will result in lower happiness and mental problems [45].

The joy of physical activity is important to be applied so that children do not stop doing physical activity. Playing has many positive impacts on children, including cognitive, affective, social, and psychomotor development. Teachers and health instructors should pay attention to physical activity for overweight children to keep them in a pleasant condition. An increase in the volume of physical activity is associated with increased levels of higher happiness [46]. Research from Richards shows that moderate to high-frequency physical activity will reduce stress levels and make people happier than people who do low physical activity [47].

Basic motion is divided into three types: locomotor, non-locomotor, and manipulative [48]. The product of this 
study refers to the basic concept of locomotor, non-locomotor, and manipulative motion, where the three movements are present in every game. Locomotor movement and non-locomotor movement, movement of the combination of hands and feet, and even using tools are included in this developed physical activity model. Overweight children have poor manipulative skills. Manipulative skills carried out by playing will help children to move in daily life [49].

The large-scale trials show that the developed play-based physical activity model brings joy to the children. Weight loss is expected to be successful with exciting and varied physical activity. After doing physical activity, it will increase the happy atmosphere [50]. An increase in the volume and frequency of physical activity will have a significant impact on happiness [51]. The joy and safety felt by overweight children in doing physical activity is an essential point in large-scale trials.

The effectiveness testing of the play-based physical activity model showed that the experimental group lost weight, while the control group gained weight. The average score (bodyweight) obtained in the experimental group during the pre-test was $49.33 \mathrm{~kg}$, decreased to 45.77 $\mathrm{kg}$ in the post-test. Whereas in the control group, the average body weight was $47.12 \mathrm{~kg}$ during the pre-test, and there was an increase during the post-test to $52.40 \mathrm{~kg}$. This shows that physical activity is beneficial for children's health.

This play-based physical activity model was developed by studying existing relevant studies. The research entitled the effect of maternal health education on physical activity and body mass index of overweight children, reference [52] reported that health education from parents would affect increasing physical activity. This is in line with this study that the teacher as education and instructor has a vital role in children's physical activity. Another survey by reference [53] on school-based interventions to reduce overweight and inactivity in children aged 6-12 years concluded that exercise 3 hours per week plus other activities outside the classroom impact decreasing the weight of the children.

Physical activity models that involve many people or in groups will be more exciting and make the participants feel happy. Physical activity correlates with happiness, according to research conducted by [54]. Playing with a group will create a fun atmosphere [55]. Activity models that involve several people or groups make social interactions more attractive and create a higher sense of enthusiasm than individual activities.

Physical activity is recommended to overcome overweight in children. Children require changes in diet and physical activity to overcome the overweight problem. This should be performed through mutual coordination between policymakers, community leaders, parents, schools, and individuals themselves [56]. The overweight problem in children is a crucial problem, and physical activity is a significant component of energy balance, using calories to move [57]. There are several ways to assess physical activity, including self-reports, with heart rate, by observation [55].

Efforts to overcome overweight can be made with physical activity that requires specific guidance [58]. This developed product is a physical activity guide that assists teachers, or health instructors guide children in physical activity to lose weight. The physical activity designed in this study also considers the facilities and infrastructure used to create safety and joy. Children will increase physical activity if a comfortable environment is provided [59]. Schools with more complete and better infrastructure will correlate with the high physical activity available for the children [60]. Mass physical activity will encourage passive individuals to be more involved [61].

Parents and health-related professions must work collaboratively to create physical activity programs for children [3]. The physical activity program implemented in school is effective in losing weight [62]. An increased physical activity carried out by physical education teachers in schools will reduce children's weight and improve fitness levels [53]. Environmental infrastructure also supports physical activity in overweight children [63]. Physical activity by playing will be more acceptable for children with the support of teachers and a comfortable school environment.

This play-based physical activity model is designed to provide the concept of playing while doing physical activity by considering the extremities of motion. Every child has their comfort or expertise in using their feet or hands. Some children prefer to use their hands than their feet, and vice versa. The difference in the physical development of children varies from one another, where the experience of movement that they have is one of the factors that influence how children can better use their hands or feet in performing specific skills [64]. The extremity of superior or lower motion is separated to facilitate the children's limitations on different abilities related to their hands and feet.

The play-based physical activity model was significantly influential and effective compared to the control group in this study. The play-based physical activity model is designed to emphasize light to moderate intensity with the concept of playing. Besides that, it is also on the extremity of the motion tools used for physical activity. Some children are more comfortable using their hands to play, but few enjoy using their feet. It requires different energy to move the feet than to move the hands [65]. Differences in the ability to use the left foot and right foot or left hand and right hand are found in both women and men [66].

Light to moderate-intensity physical activity is recommended in weight loss programs. With light to moderate intensity, it uses much fat to produce energy. Research from Gordon indicated that there is a significant 
reduction in fat with moderate-intensity exercise for six weeks [67]. Physical activity with low intensity, medium intensity, and high intensity affects the body composition of overweight [68]. Furthermore, it is concluded that moderate-intensity offers the best results in the study. All forms of physical activity designed in this study emphasize low to moderate intensity. Moderate-intensity physical activity for 75 minutes per week is recommended to maintain body composition [69]. Low-intensity physical activity showing the most effective method for weight loss in overweight children is associated with improving cognitive aspects [70].

The play-based physical activity designed for overweight children is based on theoretical studies and observations on several physical activities carried out by overweight children at school. Overweight children are more passive in their activities. Some overweight youngsters dislike sports subjects because they feel inadequate. Overweight children are less inclined to move because of their lack of agility. Overweight children take time off to eat and be silent to observe their peers' physical activity. Overweight children are less likely to exercise because they are engrossed in computer games or viewing movies on their phones. When children are overweight, they are more likely to miss school. This study was carried out in one of Yogyakarta's primary schools, specifically Sumber 1 Elementary School Yogyakarta. Where do overweight youngsters between the ages of 9 and 12 live. The results of this study are also consistent with several studies that have been conducted. Research conducted by Zamzani shows a significant effect of physical activity on overweight levels [71]. Thus, a play-based physical activity made for children has high benefits for health and well-being. With play-based physical activity, it is expected that children will enjoy every physical activity they do.

Diet, smoking, and physical activity are related aspects of lifestyle that should be addressed when dealing with the overweight problem. A change in lifestyle towards a healthy lifestyle will reduce overweight [72]. Physical activity, low BMI, and a safe distance from cigarette smoke are associated with happiness [73]. The results of Min's research show that physical activity carried out regularly by overweight children will impact happiness and reduced stress [74]. The results of this study indicate that after doing physical activity, children will experience a decrease in body weight so that which correlates with the level of health and happiness.

Based on the findings, it is confirmed that the developed physical activity model is effective for children's weight loss program with fun activities. Playing together in groups creates a more fun atmosphere and stimulates social interactions. Overweight children need a fun physical activity to avoid laziness from physical movement and social interaction. Increased physical activity has an impact on reducing levels of stress and improving happiness [75]. Physical activity can also improve the mental health and cognitive abilities of children [76].

In addition to physical activity aspects that can help overweight children lose weight, the food factor must be considered in the overweight child problem. Obesity is primarily caused by foods that are high in calories and fat. The eating of fewer vegetables and fruits contributes to the development of childhood obesity. To help youngsters lose weight, parents should limit their children's intake of high-fat and complex-carbohydrate foods. The study did not control children's eating habits, but it did explain what meals overweight youngsters should consume. Children are urged to eat high-fiber vegetables and fruits, while fatty foods, fast food, and soft drinks should be avoided. It is possible to lose weight by eating a low-calorie diet. The body must adapt to changes in eating patterns. Thus a better diet menu must be developed.

Weight loss can be achieved by engaging in play-based physical activity 25 times in 5 weeks at a low to moderate intensity. Due to the regulated intensity of play-based physical activity, the energy utilized in movement consumes more fat. Body composition will be affected if you burn fat to move. A person's weight will be affected by the lowered fat. Play-based physical activity completed in less than 60 minutes is effective for fat loss. Only fatty acids floating in the bloodstream are employed if the temperature is achieved after 20 minutes of activity. If the temperature is reached after less than 20 minutes, triacylglycerol lipase will work. As a result, you can burn fat for energy by engaging in more than 20 minutes of play-based physical activity. If there is enough oxygen, fat can be converted to energy. The movement of fatty acids from fat storage to the muscle is vital in weight loss, accomplished by reducing body fat.

Body Mass Index (BMI) measures human body composition related to being overweight or not. Doctors commonly use BMI to interpret several diseases associated with being overweight. In this study, the BMI value of all samples of the experimental group decreased in value, which means that the physical activity program succeeded in reducing the sample's weight. Some changed from obesity to overweight status and some from overweight to normal. The results showed that children who did play-based physical activity affected BMI due to changes in weight and height. Differences in height are very likely to occur because the research sample is still in its infancy. At the same time, changes in body weight occur due to the physical activity carried out. In the control group, the BMI of all samples experienced an increase in value. An increase in height also accompanied the rise in weight. Weight gain can occur if the child is not moving, overeating or sleeping patterns are not good. 


\section{Conclusion}

Weight loss program for overweight children is crucial and has many positive effects for the children. Physical activity is a safe and effective method for overweight problems in children. The results indicated that the play-based physical activity model was effective in reducing the weight of overweight children.

The results of this study can be used by sports teachers, instructors, parents, and stakeholders to solve the children's overweight problem. Due to the benefits of physical activity for overweight children, other types of physical activity that can be practiced individually without reducing its enjoyment and satisfaction should be further studied and developed.

\section{Acknowledgments}

We would like to thank Prof. Dr. Siswantoyo, S.Pd., M. Kes. AIFO, Dr. Yudanto. M. Pd, dr. Muhammad Ikhwan Zein, Sp.K.O, Saryono, S.Pd.Jas., M.Or, Geovani Akbar, S. Or, Galang Qowiyyuridho. S. Pd, Dedy Setiawan, S. Pd. Cor for their contributions, evaluation, and suggestions in this study.

\section{REFERENCES}

[1] World Health Organization (WHO), "Obesity and overweight", https://www.who.int/topics/obesity/en/(acces sed December. 2, 2020).

[2] Lobstein T, Baur L, Uauy R, IASO International Obesity TaskForce, "Obesity in children and young people: a crisis in public health," Obes rev, 2004, 5 Suppl 1, pp. 4-104. DOI: 10.1111/j.1467-789X.2004.00133.x

[3] Rich, S. S., DiMarco, N. M., Huettig, C., Essery, E. V., Andersson, E., \& Sanborn, C. F., "Perceptions of health status and play activities in parents of overweight hispanic toddlers and preschoolers," Family and Community Health, vol. 28, issue 2, pp. 130-141, 2005. DOI: 10.1097/00003727-200504000-00005

[4] World Health Organization (WHO), "The World Health Report 1998: Life in the $21^{\text {st }}$ century A vision for all", https://www.who.int/whr/1998/en/whr98_en.pdf, pp. 137 (accessed November. 2, 2018).

[5] Sri Poedji Hastoety Djaiman, Sihadi, Kencana Sari, dan Nunik Kusumawardani, "A Metaanalysis: The Prevention of Obesity in School Children," Journal of Media Litbangkes, vol. 27, no. 1, pp. 39-48, 2017. DOI: 10.22435/mpk.v27i1.4838.39-48

[6] Husain, A., Tendean, L., \& Queljoe, E. De, "Pengaruh Kelebihan Berat Badan / Overweight Terhadap Terjadinya Disfungsi Seksual Pria," Journal of PAAI eBiomedik, vol. 3, no. 3, pp. 782-785, 2015. DOI: $10.35790 /$ ebm.3.3.2015.10 143
[7] Kementerian Kesehatan RI, "Epidemi Obesitas", Kemkes dokumen ptm, http://www.p2ptm.kemkes.go.id/dokumen$\mathrm{ptm} /$ factsheet-obesitas-kit-informasi-obesitas (accessed October. 10, 2020)

[8] The Conversation, “Obesitas Mengancam Negara Berkembang, Bagaimana Kebijakan Bisa Mengendalikannya", https://theconversation.com/obesitasmengancam-negara-berkembang-bagaimana-kebijakan-bis a-mengendalikannya-89175 (accessed July. 7, 2020)

[9] Hamam Hadi, "Gizi Lebih Sebagai Tantangan Baru Dan Implikasinya Terhadap Kebijakan Pembangunan Kesehatan Nasional," Jurnal Gizi Klinik Indonesia, vol. 1, no 2, pp. 47-53, 2004. DOI: 10.22146/ijcn.17394

[10] Salvy, S. J., Roemmich, J. N., Bowker, J. C., Romero, N. D., Stadler, P. J., \& Epstein, L. H., "Effect of peers and friends on youth physical activity and motivation to be physically active," Journal of Pediatric Psychology, vol. 34, issue 2, pp. 217-225, 2009. DOI: 10.1093/jpepsy/jsn071

[11] Clement, K. And P. Ferre, "Genetics and the pathophysiology of obesity," Journal of Pediatric Research, vol. 53, no. 5, pp. 721-725, 2003. DOI: 0031-3998/03/530 $5-0721$

[12] Brendall, L.W., "Lifestyle Conselor's Guide for Weight Control," in American Health Publishing Company, 1996.

[13] Corbin, C.B., Welk, G.J., Lindsey, R., Corbin, W.R., "Concepts of Fitness and Wellness: A Comprehensive Lifestyle Approach with Powerweb/OLC Bind-in Card and HealthQuest," in McGraw-Hill College, 5th ed, 2004, pp. $1-486$

[14] Rahmatika. "Obesitas Pada Anak dan Remaja", http://www.idituban-file-wordpress.com2008/11/nh-2.pdf/ (accessed November. 9, 2018)

[15] Wirakusumah, E.S., "Cara Aman dan Efektif Menurunkan Berat Badan,” in PT Gramedia, 2nd ed, 1994, pp. 1-120.

[16] McArdle, W. D., Katch, F. I., Katch, V. L., McArdle, W. D., Katch, F. I., \& McArdle, W. D., "Essentials of exercise physiology," in Wolters Kluwer Lippincott Williams \& Wilkins, 4th ed, 2011, pp. 1-699.

[17] Kuntaraf Jonathan, Kathleen. L. K., "Olahraga Sumber Kesehatan," in Indonesia Publishing House, 9th ed, 2006, pp. 1-304.

[18] Minsoo, K., Tiago V. Barreira, Elizabeth A. Holbrook, David, A. R., "Effect Of Different Epoch Lengths On Activity Counts Using The Actigraph GT1M Accelerometer," vol. 42, issue 5, 2010, p. 482. DOI: 10.1249/01.MSS.0000385078.70668.7d

[19] Cekin, R., "Psychological Benefits of Regular Physical Activity: Evidence from Emerging Adults," Universal Journal of Educational Research, vol. 3, no. 10, pp. 710 717, 2015. DOI: 10.13189/ujer.2015.031008

[20] Kruger, J., Bowles, H. R., Jones, D. A., Ainsworth, B. E., \& Kohl, H. W, "Health-related quality of life, BMI and physical activity among US adults ( $\geq 18$ years): National physical activity and weight loss survey, 2002," International Journal of Obesity, vol. 31, no. 2, pp. 321-327, 2007. DOI: $10.1038 /$ sj.ijo.0803386

[21] Pulido, R., Banks, C., Ragan, K., Pang, D., Blake, J. J., \& 
McKyer, E. L., "The Impact of School Bullying on Physical Activity in Overweight Youth: Exploring Race and Ethnic Differences," Journal of School Health, vol. 89, no. 4, pp. 319-327, 2019. DOI: 10.1111/josh.12740

[22] Steve Stork dan Stephen W. Sanders, "Physical Education in Early Childhood," The Elementary School Journal, vol. 108, no. 3, pp. 197-206, 2008. DOI: $10.1086 / 529102$

[23] Hardman, A. E., "Physical activity and health," Nutrition Bulletin, vol. 22, issue 2, pp. 100-110, 1997. DOI: 10.1111/j.1467-3010.1997.tb01062.x

[24] Rossouw, H. A., Grant, C. C., \& Viljoen, M., "Overweight and obesity in children and adolescents: The South African problem," South African Journal of Science, vol. 108, no. 5-6, pp. 1-7, 2012. DOI: 10.4102/sajs.v108i5/6.907

[25] Rini, M. T., Hardika, B. D., \& Suryani, K., "Penurunan Berat Badan pada Remaja Obesitas Menggunakan Hipnoterapi," Jurnal Keperawatan Silampari, vol. 4, no.1, pp. 135-141, 2020. DOI: 10.31539/jks.v4i1.1604

[26] Natale, R. A., Messiah, S. E., Asfour, L., Uhlhorn, S. B., Delamater, A., \& Arheart, K. L., "Role modeling as an early childhood obesity prevention strategy: Effect of parents and teachers on preschool children's healthy lifestyle habits," Journal of Developmental and Behavioral Pediatrics, vol. 35, no. 6, pp. 378-387, 2014. DOI: 10.1097/DBP.0000000 000000074

[27] Samosir, A. S., Sinaga, F. A., IP, J., Sinaga, R. N., \& Marpaung, D. R., "Senam Aerobik Intensitas Sedang Menurunkan Kadar Kolesterol Total Dan Indeks Massa Tubuh Wanita Penderita Obesitas," Sains Olahraga : Jurnal Ilmiah Ilmu Keolahragaan, vol. 2, no. 2, pp. 31, 2019. DOI: $10.24114 /$ so.v2i2.11292

[28] Simopoulos, A. P., "Nutrition and Fitness: Obesity, the Metabolic Syndrome, Cardiovascular Disease, and Cancer," 5th International Conference on Nutrition and Fitness Athens, June, 2004, pp. 12-24. https://www.karger.com/Ar ticle/Pdf/88201

[29] Sharkey, B.J., "Kebugaran dan Kesehatan," in Raja Grafindo Persada, 1st, 2003, p. 385.

[30] Ortega, F. B., Ruiz, J. R., \& Sjöström, M., "Physical activity, overweight and central adiposity in Swedish children and adolescents: the European Youth Heart Study," International Journal of Behavioral Nutrition and Physical Activity, vol. 4, no. 61, pp. 1-10, 2007. DOI: 10.1186/1479-5868-4-61

[31] Nurul Auliah, A., Latifah Nur'aeni, A., Nur Hidayati, E., \& Ridwan Yusup, I., "Hubungan Pola Hidup Dan Berat Badan Mahasiswa Pendidikan Biologi Semester 7a," BIO EDUCATIO: The Journal of Science and Biology Education, vol. 5, no.1, pp. 24-29, 2020. DOI: 10.31949/be.v5i1.1909

[32] Mark, A. E., \& Janssen, I., "Influence of Bouts of Physical Activity on Overweight in Youth," American Journal of Preventive Medicine, vol. 36, no. 5, pp. 416-421, 2009. DOI : 10.1016/j.amepre.2009.01.027

[33] Simon, C., Schweitzer, B., Oujaa, M., Wagner, A., Arveiler, D., Triby, E., ... Platat, C., "Successful overweight prevention in adolescents by increasing physical activity: A 4-year randomized controlled intervention," International
Journal of Obesity, vol. 32, issue 10, pp. 1489-1498, 2008. DOI: $10.1038 /$ ijo.2008.99

[34] Trost, S. G., Sirard, J. R., Dowda, M., Pfeiffer, K. A., \& Pate, R. R., "Physical activity in overweight and nonoverweight preschool children," International Journal of Obesity, vol. 27, issue 7, pp. 834-839, 2003. DOI: 10.1038/sj.ijo.0802311

[35] Holly, R.G and Shaffrath, J.D., "Cardiorespiratory Endurance.," in Rotman, J.L (Ed), ACSM's Resource Manual for Guidelines for Exercise Testing and Prescription, 4th ed, Lippincott Williams \& Wilkins, 2011, pp. 449-459.

[36] Bish, C. L., Blanck, H. M., Serdula, M. K., Marcus, M., Kohl, H. W., \& Khan, L. K., "Diet and physical activity behaviors among Americans trying to lose weight: 2000 behavioral risk factor surveillance system," Obesity Research, vol. 13, no.3, pp. 596-607, 2005. DOI: 10.1038/oby.2005.64

[37] Piqueras, J. A., Kuhne, W., Vera-Villarroel, P., Van Straten, A., \& Cuijpers, P., "Happiness and health behaviours in Chilean college students: A cross-sectional survey," BMC Public Health, 11, 443, 2011. DOI: 10.1186/1471-2458-11 $-443$

[38] Cornelisse-Vermaat, J. R., Gerri, A., van Ophem, J. A. C., \& van den Brink, H. M., "Body mass index, perceived health, and happiness: Their determinants and structural relationships," Social Indicators Research, vol 79, issue 10, pp. 143-158, 2006. DOI: 10.1007/s11205-005-4097-7

[39] Pranoto, Y. K. S., \& Hong, J., "Gender preferences in play companions that lead to happiness: a case study on Indonesian children," Early Child Development and Care, vol. 190, no. 11, pp. 1802-1819, 2020. DOI: $10.1080 / 03004430.2018 .1550751$

[40] Moore, A., \& Lynch, H., "Understanding a child's conceptualisation of well-being through an exploration of happiness: The centrality of play, people and place," Journal of Occupational Science, vol. 25, no. 1, pp. 124141, 2017. DOI: $10.1080 / 14427591.2017 .1377105$

[41] Ginsburg, K. R., Shifrin, D. L., Broughton, D. D., Dreyer, B. P., Milteer, R. M., Mulligan, D. A., ... Smith, K., "The importance of play in promoting healthy child development and maintaining strong parent-child bonds," The American Academy of Pediatrics, vol. 119, no. 1, pp. 182-191, 2007. DOI: $10.1542 /$ peds.2006-2697

[42] Maher, C. A., Toohey, M., \& Ferguson, M., "Physical activity predicts quality of life and happiness in children and adolescents with cerebral palsy," Disability and Rehabilitation, vol. 38, no. 9, pp. 865-869, 2016. DOI: $10.3109 / 09638288.2015 .1066450$

[43] Van Woudenberg, T. J., Bevelander, K. E., Burk, W. J., \& Buijzen, M., "The reciprocal effects of physical activity and happiness in adolescents," International Journal of Behavioral Nutrition and Physical Activity, vol. 17, no. 1, pp. 1-10, 2020. DOI: 10.1186/s12966-020-01058-8

[44] Salmon, J., Ball, K., Hume, C., Booth, M., \& Crawford, D., "Outcomes of a group-randomized trial to prevent excess weight gain, reduce screen behaviours and promote physical activity in 10-year-old children: Switch-Play," International Journal of Obesity, vol. 32, no. 4, pp. 601-612, 


\section{DOI: 10.1038/sj.ijo.0803805}

[45] Rasciute, S. \& Downward, P., Health or happiness? what is the impact of physical activity on the individual?," Kyklos, vol. 63, no. 2, pp. 256-270, 2010. DOI: 10.1111/j.1467-6435.2010.00472.x

[46] Richards, J., Jiang, X., Kelly, P., Chau, J., Bauman, A., \& Ding, D., "Don't worry, be happy: Cross-sectional associations between physical activity and happiness in 15 European countries," BMC Public Health, vol. 15, no. 1, pp. 1-8, 2015. DOI: 10.1186/s12889-015-1391-4

[47] Moljord, I. E. O., Moksnes, U. K., Eriksen, L., \& Espnes, G. A., "Stress and happiness among adolescents with varying frequency of physical activity," Perceptual and Motor Skills, vol. 113, no.2, pp. 631-646, 2011. DOI: 10.2466/02.06.10.13.PMS.113.5.631-646

[48] Hidayat, A., "Peningkatan Aktivitas Gerak Lokomotor, Nonlokomotor Dan Manipulatif Menggunakan Model Permainan Pada Siswa Sekolah Dasar," Jurnal Pendidikan Jasmani Dan Olahraga, vol. 2, no. 2, pp. 21, 2017. DOI: 10.17509/jpjo.v2i2.8175

[49] Ardanari, P., Mintarto, E., Tuasikal, A. R. S., \& Suroto, S., "Aktivitas Bermain Meningkatkan Keterampilan Manipulatif: Review Jurnal," Gelanggang Pendidikan Jasmani Indonesia, vol. 4, no. 1, pp. 79, 2020. DOI: 10.17977/um040v4i1p73-78

[50] Wang, F., Orpana, H. M., Morrison, H., De Groh, M., Dai, S., \& Luo, W., "Long-term association between leisure-time physical activity and changes in happiness: Analysis of the prospective National Population Health Survey," American Journal of Epidemiology, vol. 176, issue 12, pp. 1095-1100, 2012. DOI: 10.1093/aje/kws199

[51] De Souto Barreto, P., "Direct and indirect relationships between physical activity and happiness levels among older adults: A cross-sectional study," Aging and Mental Health, vol. 18, issue 7, pp. 861-868, 2014. DOI: $10.1080 / 13607863.2014 .896863$

[52] FAO, World Health Organization, "Vitamin and mineral requirement sin human nutrition," in WHO Library Cataloguing-in-Publication Data, 2nd, 2014, pp. 1-341.

[53] Jansen, W., Raat, H., Zwanenburg, E. J. Van, Reuvers, I., Van Walsem, R., \& Brug, J., "A school-based intervention to reduce overweight and inactivity in children aged 6-12 years: Study design of a randomized controlled trial," BMC Public Health, 8, pp. 1-9, 2008. DOI: 10.1186/1471-2458-8-257

[54] Fisher, J. J., Kaitelidou, D., \& Samoutis, G., "Happiness and physical activity levels of first year medical students studying in Cyprus: A cross-sectional survey," BMC Medical Education, vol. 19, no. 1, pp. 1-7. DOI: 10.1186/s12909-019-1790-9

[55] Bekker, T., Sturm, J., Wesselink, R., Groenendaal, B., \& Eggen, B., "Interactive play objects and the effects of open-ended play on social interaction and fun," Proceedings of the 2008 International Conference on Advances in Computer Entertainment Technology, December, 2008, pp. 389-392. DOI: $10.1145 / 1501750.1501841$

[56] James O. Hill, PhD*, and Frederick L. Trowbridge, M., Childhood Obesity: Future Directions and Research
Priorities," Pediatrics, vol. 101, no. 3, pp. 570-574, 1998. DOI: $10.1542 /$ peds.101.3.570

[57] Kohl, H. W., \& Hobbs, K. E., "Development of physical activity behaviors among children and adolescents," Pediatrics, vol. 101, no. 2, pp. 549-554, 1998. https://pediatrics.aappublications.org/content/pediatrics/10 1/Supplement_2/549.full.pdf

[58] Faith, M. S., Leone, M. A., Ayers, T. S., Heo, M., \& Pietrobelli, A., "Weight criticism during physical activity, coping skills, and reported physical activity in children," Pediatrics, vol. 110, no. 2, 2002. DOI: 10.1542/peds.110.2.e23

[59] Farley, T. A., Meriwether, R. A., Baker, E. T., Watkins, L. T., Johnson, C. C., \& Webber, L. S., "Safe play spaces to promote physical activity in inner-city children: Results from a pilot study of an environmental intervention," American Journal of Public Health, vol. 97, no. 9, pp. 16251631, 2007. DOI: 10.2105/AJPH.2006.092692

[60] Alemdag, C., Alemdag, S., \& Ozkara, A. B., "Physical Activity As a Determinant of Subjective Happiness," Baltic Journal of Sport and Health Sciences, vol. 4, no. 103, pp. 2 10, 2006. DOI: 10.33607/bjshs.v4i103.66

[61] Stevinson, C., \& Hickson, M., "Changes in physical activity, weight and wellbeing outcomes among attendees of a weekly mass participation event: A prospective 12-month study," Journal of Public Health (United Kingdom), vol. 41, no. 4, pp. 807-814, 2018. DOI: 10.1093/pubmed/fdy 178

[62] Jansen, W., Borsboom, G., Meima, A., Zwanenburg, E. J. Van, MacKenbach, J. P., Raat, H., \& Brug, J., "Effectiveness of a primary school-based intervention to reduce overweight," International Journal of Pediatric Obesity, vol. 6, no. 2-2, pp. 70-77, 2011. DOI: $10.3109 / 17477166.2011 .575151$

[63] Veugelers, P., Sithole, F., Zhang, S., \& Muhajarine, N., "Neighborhood characteristics in relation to diet, physical activity and overweight of Canadian children," International Journal of Pediatric Obesity, vol. 3, no. 3, pp. 152-159, 2008. DOI: 10.1080/17477160801970278

[64] Rohmatin, T., \& Wulan, B. R. S., "Kemampuan motorik kasar anak sekolah dasar berdasarkan perbedaan status ekonomi keluarga," Premiere Educandum: Jurnal Pendidikan Dasar Dan Pembelajaran, vol. 9, no. 2, pp. 172, 2019. DOI: $10.25273 /$ pe.v9i2.5024

[65] Simonen, R. L., Battie, M. C., Videman, T., \& Gibbons, L. E., "Comparison of Foot and Hand Reaction Times among Men: A Methodologic Study Using Simple and Multiple-Choice Repeated Measurements," Perceptual and Motor Skills, 80(3c), 1995, pp. 1243-1249. DOI: 10.2466/pms.1995.80.3c. 1243

[66] Barut, C., Ozer, C. M., Sevinc, O., Gumus, M., \& Yunten, Z., "Relationships between hand and foot preferences," International Journal of Neuroscience, vol. 117, no. 2, pp. 177-185, 2007. DOI: 10.1080/00207450600582033

[67] Fisher, G., Brown, A. W., Bohan Brown, M. M., Alcorn, A., Noles, C., Winwood, L., ... Allison, D. B., "High intensity interval- vs moderate intensity- training for improving cardiometabolic health in overweight or obese males: A Randomized controlled trial," PLoS ONE, vol. 10, no. 10, pp. 1-15. DOI: 10.1371/journal.pone.0138853 
[68] Elhakeem, A., Hannam, K., Deere, K. C., Hartley, A., Clark, E. M., Moss, C., ... Tobias, J., "Physical Activity Producing Low, but Not Medium or Higher, Vertical Impacts Is Inversely Related to BMI in Older Adults: Findings from a Multicohort Study," Journals of Gerontology - Series A Biological Sciences and Medical Sciences, vol. 73, no. 5, pp. 643-651. DOI: 10.1093/gerona/glx176

[69] Frimpong, E., Dafkin, C., Donaldson, J., Millen, A. M. E., \& Meiring, R. M., "The effect of home-based low-volume, high-intensity interval training on cardiorespiratory fitness, body composition and cardiometabolic health in women of normal body mass and those with overweight or obesity: Protocol for a randomized controlled trial," BMC Sports Science, Medicine and Rehabilitation, vol. 11, no. 1, pp. 112, 2019. DOI: 10.1186/s13102-019-0152-6

[70] Crova, C., Struzzolino, I., Marchetti, R., Masci, I., Vannozzi, G., Forte, R., \& Pesce, C., "Cognitively challenging physical activity benefits executive function in overweight children," Journal of Sports Sciences, vol. 32, no. 3 , pp. 201-211, 2014. DOI: 10.1080/02640414.2013.8 28849

[71] Zamzani, M., Hadi, H., \& Astiti, D., “Aktivitas fisik berhubungan dengan kejadian obesitas pada anak sekolah dasar," Jurnal Gizi dan Dietetik Indonesia, vol. 4, no. 3, pp. 123-128, 2016. DOI: 10.21927/ijnd.2016.4(3).123-128

[72] Bulló, M., Garcia-Aloy, M., Martínez-González, M. A.,
Corella, D., Fernández-Ballart, J. D., Fiol, M., ... Salas-Salvadó, J., Association between a healthy lifestyle and general obesity and abdominal obesity in an elderly population at high cardiovascular risk," Preventive Medicine, vol. 53, no. 3, pp. 155-161, 2011. DOI: 10.1016/j.ypmed.2011.06.008

[73] Fararouei, M., Brown, I. J., Akbartabar Toori, M., Estakhrian Haghighi, R., \& Jafari, J., "Happiness and health behaviour in Iranian adolescent girls," Journal of Adolescence, vol. 36, no. 6, pp. 1187-1192, 2013. DOI: 10.1016/j.adolescence.2013.09.006

[74] Min, J. H., Lee, E. Y., Spence, J. C., \& Jeon, J. Y., "Physical activity, weight status and psychological well-being among a large national sample of South Korean adolescents," Mental Health and Physical Activity, vol. 12, pp. 44-49, 2017. DOI: 10.1016/j.mhpa.2017.02.004

[75] Föhr, T., Pietilä, J., Helander, E., Myllymäki, T., Lindholm, H., Rusko, H., \& Kujala, U. M., "Physical activity, body mass index and heart rate variability-based stress and recovery in 16275 Finnish employees: A cross-sectional study," BMC Public Health, vol. 16, no. 1, 2016. DOI: 10.1186/s12889-016-3391-4

[76] Lubans, D., Richards, J., Hillman, C., Faulkner, G., Beauchamp, M., Nilsson, M., ... Biddle, S., "Physical activity for cognitive and mental health in youth: A systematic review of mechanisms," Pediatrics, vol. 138, no. 3, 2016. DOI: $10.1542 /$ peds.2016-1642 